\title{
Animation Short Film on Students' Narrative Text Writing Ability (A Mixed Method)
}

\author{
Muhamad Nazarudin Asyidiq", Riska Oktariani, Akmal \\ Department of English Education, Universitas Ahmad Dahlan, Indonesia
}

Received February 28, 2020; Revised April 2, 2020; Accepted April 19, 2020

Copyright $\odot 2020$ by authors, all rights reserved. Authors agree that this article remains permanently open access under the terms of the Creative Commons Attribution License 4.0 International License

\begin{abstract}
Teaching the English narrative genre text writing had become more challenging than ever because the students did not learn enough on English writing so the teacher needs to be creative and innovative in teaching learning. This paper investigates the effect of animation short film on the writing ability of students in narrative genre text. The objectives of the study were to identify the effect and the perceptions of the students on the use of animation short film in narrative text writing ability. The researchers employed a convergent parallel mixed method design and the data collected by using writing assessment test and questionnaire. Furthermore, the participants were 36 students who come from one of the senior high school in Ciamis regency, West Java province. The collected data were analyzed by quantitative and qualitative research design. The results of the study show that there is a significant effect on students' narrative text writing ability after having learning treatment by using animation short film, and there are positive perceptions on the usage of animation short film in narrative text writing. Thus, the conclusions are the animation short film can improve students' ability in writing narrative text. This study recommends students to improve their narrative text writing ability and then publish their work in the journal.
\end{abstract}

Keywords Animation Short Film, Mixed Method, Narrative Text, Writing Ability

\section{Introduction}

Teaching English narrative text had become more challenging than ever. The reasons are the students did not learn enough on English writing, tenses usage in sentences, less of vocabulary, hard developing the story, generic structure recognition, and difficult to make the title from the theme [1]. In addition, the students do not write a list of their ideas; the students just directly wrote a text without doing the process of writing [2].

In order to help the students' proficiency of writing skill, English teachers had to provide innovative teaching materials that built a link among the young generation, school culture and technology in the school follows the content of learning [3]. Regarding the problem, multimedia could be an innovative solution proved by transferring tests that produced average of score more than $50 \%$ participants' expose, even the effect of multimedia in multiple applications and in one case produces over than $75 \%$ more innovative solutions generated [4]. Besides, the students prefer to use media in their learning practice as their daily activities which always use mobile phone [5].

One of the media which can help students' narrative text writing ability is animation short film [6]-[8]. Ruusunen [6] stated that film is one of the useful media and has several advantages compared to the more traditional teaching styles, such as teaching oral communication, teaching writing, teaching vocabulary, and grammar. He added that the feedback from pupils about using films in teaching writing has been positive. Another term is animation. As a researcher, Lata \& Pooja [8] stated that motion on the screen is important for attracting onlooker interest. Students can focus on the screen without losing their attention. Besides that, the animations can elaborate crucial contents explicitly to students, has beneficial to learning, makes students interested in learning, and the animations facilitated the content memorization [7].

Many researchers had revealed that short film used in the EFL classroom could be a useful part of the learning [9][11]. Ismaili [9] said that the film could attract the attention of students, present the language that written in course-book naturally. Quantitatively, the experimental group that used the subtitled film performed a significant difference and better than the student without using film [10]. Also, Kabadayi [11] proved that the multimedia education (one of them was film) made students could remember the knowledge.

This study also discussed about using animation short 
film used by teacher in classroom interaction. Unfortunately, the previous researchers were on the use of short films for increasing student's attention and motivation. Thus, this study filled the gap and investigated how animation short films can be effective to improve students' narrative text writing ability.

\section{Literature Review}

Dealing with writing, Nunan [12] stated, "Writing is a media to communicate among writer and readers". Therefore, writing must be understandable so the readers can understand the purpose of the text. Writing also has a lot of benefits [13]. Klimova explained that the writing helps to express the one's personality, nurture communication, make persuasive and logical arguments, afford a person an opportunity to continue the reflection of his/her ideas, acquire thinking skills, give and accept feedback, and draw up for employment and school. There were several processes that could be used by the writer. Peha [14] proposed writing processes such as pre-writing, drafting, sharing, revising, editing, publishing, and assessing. The process of writing stages were also found by Abbas, Hashima, \& Aziz study [15], the writing processes were prewriting, planning, drafting, pausing and reading, and revising and editing.

Bordwell \& Thompson [16] stated that the animated film is a motion picture, the photograph drawing of the camera, or the model from 3 dimensions such as Wallace and Gommit movies. Animation has a positive function to satisfy the curiosity of children and provide the contribution to family behavior and real-life experiences [17]. Animated film also based on the violence of comic contextualization coupled with the ability of young children to differentiate fantasy from reality and good from bad, may eliminate the possibility that the children will commit the attractiveness manner shown in animated films on other in real life [18]. For instance, two cartoons show the strong family who ties in cultural connection and lifestyles entitled Pepee and Caillou so that the effect is the behavior of care about senior family members which become a common entity in Turkish family [19].

The narrative text was a text which aimed to entertain or amuse the reader. The generic structures of narrative text were orientation, complication, resolution, and re-orientation [20]. Orientation was the opening paragraph. It has when and where the story happened and introduced the participant characters who involved in the narrative, whereas, complication told about the problem arising which escort to the crisis or climax for the main character. Then the resolution was when the story discovers a solution to a crisis, therefore it guided the story to a happy or sad ending. Moreover, re-orientation was a part of story to the reversal condition, a closing remark, and optional. It contained the author advice or admonition. In writing a narrative text, the author had to recognize the time, places, and character so that the reader will be easy to comprehend the story path, to identify the character's name, the adjectives to characters, and the information related to the act of certain character.

The researcher adapted some film criteria to be used in choosing suitable film to teaching [21]. The film criteria were as follows:

1. Related to the school curriculum policy program;

2. Providing the opportunities for all students regarding with race, gender, moral value, and sexuality;

3. Relevant to the students' ages especially their intellect, emotion, society, and the development of culture;

4. Easy to understand by learners;

5. The film duration is about 2-8 minutes.

The researcher also provided several activities in implementing animation short films in the writing process, such as previewing activities, viewing activities, and post-viewing activities. [22]. In conducting the animation short film in the teaching-learning process, this research provided several steps of teaching such as opening activity, core activity, and closing activity.

To know the quality of students' work in writing product, it needed the writing assessment. The purpose was to render judgment regarding with students writing quality. Also, there were several kinds of assessing the writing product, such as primary trait scoring, holistic scoring, and analytic scoring. In this research, the analytic writing rubric assessment was used as a tool to gain the students' feedback.

\section{Materials and Methods}

Research design conducted in this study was convergent parallel mixed method design. The researcher conducted a pre-experimental design for quantitative data, then one group pre-test and post-test as the instrument of the study. Furthermore, for qualitative design, the researcher collected by using questionnaire. Those were conducted for answering the first and the second research question.

In this study, the quantitative method had been used to acquire data from the results of the experimental application of animation short film, whereas qualitative method had been used to understand the relationship between results acquired by students after treatment. The students' scores gained after post-test had been compared with the qualitative data collection results. For the test, we made the writing assessment rubric adapted from Jacobs et. al. The rubric can be seen at Table 1 . 
Table 1. Writing rubric assessment adapted from Jacobs et al.

\begin{tabular}{|c|c|c|c|}
\hline \multicolumn{4}{|c|}{ Name : ............................ } \\
\hline \multicolumn{4}{|c|}{ Class : ............................... } \\
\hline Criteria & Pts & Indicators & Score \\
\hline \multirow{4}{*}{ Content } & 4 & Relevant to the topic and easy to understand. & \\
\hline & 3 & Rather relevant to the topic and easy to understand. & \\
\hline & 2 & Relevant to the topic but is not quite easy to understand. & \\
\hline & 1 & Irrelevant to the topic and not quite easy to understand & \\
\hline \multirow{4}{*}{ Organization } & 4 & Most of the sentences are related to main idea. & \\
\hline & 3 & Some sentences are related to the main idea. & \\
\hline & 2 & Few sentences are related to the main idea. & \\
\hline & 1 & The sentences are unrelated to each other. & \\
\hline \multirow{4}{*}{ Mechanic } & 4 & A few errors of spelling, capitalization and punctuation. & \\
\hline & 3 & Occasional errors of spelling, capitalization, and punctuation. & \\
\hline & 2 & Frequent errors of spelling, capitalization, and punctuation. & \\
\hline & 1 & Dominated by errors of spelling, capitalization, and punctuation. & \\
\hline \multirow{4}{*}{ Grammar } & 4 & There is almost no error in the use of sentence. & \\
\hline & 3 & There are few errors in the use of sentence. & \\
\hline & 2 & There are many errors in the use of sentence. & \\
\hline & 1 & Almost all sentences contain errors. & \\
\hline \multirow{4}{*}{ Vocabulary } & 4 & Many vocabulary variations. & \\
\hline & 3 & Few vocabulary variations. & \\
\hline & 2 & Almost no vocabulary variations. & \\
\hline & 1 & Lack of vocabulary variations. & \\
\hline
\end{tabular}

The population of this study was the eleventh grade of science program in a senior high school in Ciamis academic year 2017/2018. As Fraenkel et al. [23] said that cluster random sampling is a technique of sampling by choosing groups, not individuals, and randomly selected. Thus, the researcher selected a particular classes randomly from fourteen eleventh grade, the selection of the sample used the lottery method as proposed by Singh [24]. The sample of this study was taken by using cluster random sampling. There are 36 learners who joined in the study. To reach the data, the researcher conducted a writing assessment test and shared the questionnaire in the last meeting.

In analyzing the data, computation static proposed by Burns [25] who applied to find out the effect of animation short film on students' narrative text writing ability. In identifying the perceptions written by students, the researcher adapted the theories analyzing steps from Creswell [26].

\section{Findings}

As it is an mixed method analyses study, the findings mainly deal with the all research questions which revealed that the students performed better in writing narrative test in the same manner as their scores increased significantly, and they felt good in using the animation short film.

Firstly, the researcher provided the result of pre-test and post-test of each group. It was related with the ways that must be conducted as proposed by Burns (2000, p. 157). Based on the computation, the researcher found that the highest score of pre-test is 95, the lowest score of pre-test is 45 , and the mean score of pre-test is 68.47 . Besides that, the highest score of post-test is 100 , the lowest score of post-test is 60 , and the mean score of post-test is 77.64 . Related to the data, the researcher found that the mean of post-test is higher than the mean of pre-test.

Besides, based on statistical research, null hypotheses $\left(\mathrm{H}_{0}\right)$ could be rejected if $\mathrm{t}$-observed was less than $\mathrm{t}$-critical value. On the other hand, alternative hypotheses $\left(\mathrm{H}_{1}\right)$ could be accepted if t-observed was bigger than $\mathrm{t}$-critical value. Thus, null hypotheses $\left(\mathrm{H}_{0}\right)$ was rejected and the alternative hypotheses $\left(\mathrm{H}_{1}\right)$ was accepted. In conclusion, there was a significant effect on students' narrative text writing ability after acquiring learning treatment using the animation short film.

Dealing with the normality distribution, the researcher provided the result based on the Saphiro-Wilk test by computation using SPSS 22. The table showed the analysis 
of pretest and posttest such as maximum, minimum, mean, and median score that could be described in the table 2 .

Table 2. Descriptives

\begin{tabular}{|c|c|c|c|c|}
\hline \multicolumn{3}{|c|}{ Group } & Statistic & $\begin{array}{c}\text { Standard } \\
\text { Error }\end{array}$ \\
\hline \multirow{13}{*}{ Pre test } & \multicolumn{2}{|c|}{ Mean } & 68,7500 & 2,28326 \\
\hline & \multirow{2}{*}{$\begin{array}{l}95 \% \text { Confidence } \\
\text { Interval for Mean }\end{array}$} & Lower B. & 64,1147 & \\
\hline & & Upper B. & 73,3853 & \\
\hline & \multicolumn{2}{|c|}{$5 \%$ Trimmed Mean } & 68,6111 & \\
\hline & \multicolumn{2}{|c|}{ Median } & 65,0000 & \\
\hline & \multicolumn{2}{|c|}{ Variance } & 187,679 & \\
\hline & \multicolumn{2}{|c|}{ Std. Deviation } & 13,69958 & \\
\hline & \multicolumn{2}{|c|}{ Minimum } & 45,00 & \\
\hline & \multicolumn{2}{|c|}{ Maximum } & 95,00 & \\
\hline & \multicolumn{2}{|c|}{ Range } & 50,00 & \\
\hline & \multicolumn{2}{|c|}{ Interquartile Range } & 20,00 & \\
\hline & \multicolumn{2}{|c|}{ Skewness } & ,304 & ,393 \\
\hline & \multicolumn{2}{|c|}{ Kurtosis } &,- 964 & ,768 \\
\hline \multirow{13}{*}{$\begin{array}{l}\text { Post } \\
\text { test }\end{array}$} & \multicolumn{2}{|c|}{ Mean } & 77,6389 & 1,66054 \\
\hline & \multirow{2}{*}{$\begin{array}{l}95 \% \text { Confidence } \\
\text { Interval for Mean }\end{array}$} & Lower B. & 74,2678 & \\
\hline & & Upper B. & 81,0100 & \\
\hline & \multicolumn{2}{|c|}{ 5\% Trimmed Mean } & 77,6543 & \\
\hline & \multicolumn{2}{|c|}{ Median } & 80,0000 & \\
\hline & \multicolumn{2}{|c|}{ Variance } & 99,266 & \\
\hline & \multicolumn{2}{|c|}{ Std. Deviation } & 9,96323 & \\
\hline & \multicolumn{2}{|c|}{ Minimum } & 60,00 & \\
\hline & \multicolumn{2}{|c|}{ Maximum } & 95,00 & \\
\hline & \multicolumn{2}{|c|}{ Range } & 35,00 & \\
\hline & \multicolumn{2}{|c|}{ Interquartile Range } & 15,00 & \\
\hline & \multicolumn{2}{|c|}{ Skewness } &,- 215 &, 393 \\
\hline & \multicolumn{2}{|c|}{ Kurtosis } &,- 907 & ,768 \\
\hline
\end{tabular}

As the final result which was known in the table 2, the significant value (two-tailed) was 0.064 and 0.065 . Then, $\mathrm{H}_{0}$ was rejected if the significant value lower than $0.05 \mathrm{a}=$ $5 \%$ ). Because the significant value (two-tailed) was bigger than a $(0.064>0.05)$ and $(0.065>0.05)$. It meant that $\mathrm{H}_{0}$ was accepted and $\mathrm{H}_{1}$ was rejected. Therefore, it could be interpreted that both pretest and posttest scores were in the normal distribution. Look at the test of normality in table 3 .

Table 3. Tests of Normality

\begin{tabular}{|c|c|c|c|c|c|c|}
\hline \multirow{2}{*}{ Group } & \multicolumn{2}{|c|}{ Kolmogorov-Smirnov } & \multicolumn{3}{c|}{ Shapiro-Wilk } \\
\cline { 2 - 7 } & Statistic & Df & Sig. & Statistic & df & Sig. \\
\hline Pre test &, 191 & 36 &, 002 &, 943 & 36 &, 064 \\
\hline Post test &, 159 & 36 &, 022 &, 943 & 36 &, 065 \\
\hline
\end{tabular}

Besides testing the normality, the researcher also tested the homogeneity. The output was the variances in which resulted by SPSS 22. The table showed the score of Levene statistic (1,401), df1 (7), df2 (28), and the final result showed that $p$-value $>0.05$ in which the $p$-value 0.244 was greater than $0.05(0.244>0.05)$. Based on the test criteria, the variance of the data was homogenous. The result of homogeneity test could be seen in table 4 .

Table 4. Test of Homogeneity of Variances

\begin{tabular}{|c|c|c|c|}
\hline Levene Statistic & df1 & df2 & Significance \\
\hline 1,401 & 7 & 28 &, 244 \\
\hline
\end{tabular}

Whereas to answer the second research question, this study gained that animation short film had a positive effect on students' narrative text writing ability as proven by Haghverdy [27] indicating that the implementation of film has a significant effect to increase the student ability in their listening, vocabulary, reading, and grammar. Besides, the animation short film gives a valuable contribution and new culture to the flipped classroom in the 21 st century in term of educational technology development [28] and it gives more valuable time to students and teacher interaction by online forum or classroom interaction because the animation short film can be shared to the students' devices such mobile phone and laptop so they can discuss the film everywhere and every time [29]. That is why, the students learn more actively to improve their narrative text writing ability.

\section{Discussion}

Hereinafter, we would like to discuss the questionnaire that had been shared to the students. However, there were two students who did not answer the question because they did not attend to the instructional process.

The first question was about the beneficial effect of animation short film on students' narrative text writing ability. The result showed that there were 34 students (94\%) who answered yes. The students answered that the animation short film eases students to understand the subject of the narrative text, learn how to write narrative text, learn how to learn a good writing, and improve their vocabulary. It was congruent with Merindriasari's study [30] indicating that the animated short film gave a strong affect on teaching English of narrative writing.

The second question was about student's agreement to learn by using animation short film. The result showed that 33 students' (92\%) agreed because the students felt entertained and fun, even they felt easier, helped and can improve their imagination. Meanwhile, there was 1 student (3\%) said no because the student did not want to think about this question. In line with this, the animation short film has gotten the students' motivation, interest, and curiosity [31].

The third question was about the help of animation short film to students' understanding of the narrative text subject. 
There were 25 students (75\%) said yes that the animation short film helped them to learn narrative text. The reasons were that the animation short film eased their learning of narrative text and helped them to understand how to write orientation, problem, re-orientation so that the generic structure of the narrative text can be completed. Furthermore, the students said that they felt it fun and interesting. Also, it could make the student creative, not tired, and more feel the situation than read the books. However, there were 7 students (19\%) said no because they were still confused and difficult to understand the subject. It was supported by Ghaderi \& Afshinfar's study [32], they stated that the use of animated video could elevate the students' intake and retention of idioms.

The fourth question was about the student's interest if the teacher teaches narrative text using animation short film. The result showed that 31 students $(86 \%)$ said yes that the students were interested in the animation short film which becomes a teaching aid on narrative subject. The reasons were that the students were fun, enjoyed while they were writing, interested, and easy to create narrative text. It was because the animation short film gave them inspiration for writing narrative text [33]. Whereas, there were 3 students (8\%) did not like writing because they were still difficult to understand.

Finally, the fifth question was about the advantage of animation short film in writing narrative text. Students answered that 29 students $(81 \%)$ said yes because the animation short film gave them an inspiration, imagination, and knowledge, so that they can write narrative text easily and creatively. Also it trained their language, vocabulary, capitalization usage, punctuation marks, so that the students comprehend to write a good narrative. However, there were 5 students (14\%) said no because the parts of animation short film gave an unclear information. In this term, the animation short film revealed that there was a significant effect on the experimental group who used the animated film as the score was bigger than the control group without treatment [34].

Some previous studies had analysed using animation short film used by the teacher in classroom interaction. Even so, the researcher attempted to analyse with the different purpose of identifying the data than previous studies. Thus, in the present study, the researcher analysed and explored more focus on the effect of animation short film on teaching, particularly on student's narrative text ability. In summary, both of the results between one group pre-test post-test and questionnaire showed that the animation short story had a positive effect on students' narrative text writing ability.

\section{Conclusions}

This study drew some conclusions based on the research finding and relevant to research questions. Firstly, there was a significant effect on students' narrative text writing ability after acquiring the animation short film. To conclude, it was assumed that the animation short film has a good effect on students' narrative text writing ability. Meanwhile, to answer the second research question, the students' perceptions were positive in general.

The usage of animation short film was effective in improving learners' narrative text writing ability. It made the students enjoy learning the material of writing narrative text. They were motivated and got challenges in improving their writing comprehension. However, a small part of the students did not agree with the content of the questionnaire that animation short film is effective in teaching writing narrative text.

Actually, this study had some advantages and also weaknesses which should be repaired by other researchers in order to make the study better. In this case, the advantages of this study are addressed toward the English educational field in supporting the teaching methodology to be integrated in the process of teaching learning. Besides, this study was only concerned about the scope of senior high school. Thus, the researcher desiderated that it was necessary to conduct the study for further researchers in other level of education in order to produce more specific result related to the effect of animation short film in education.

\section{Acknowledgements}

The researcher expressed their sincere gratitude to UAD for the research recommendation and to the headmaster of senior high school for enabling the team to conduct an experiment at SMAN 1 Ciamis.

\section{REFERENCES}

[1] A. H. Qomar, "An Analysis of the Third Semester Students' Ability in Developing Narrative Text of English Education Study Program in Muhammadiyah University of Metro," Premise J., vol. 5, no. 1, pp. 24-47, 2016.

[2] E. Nurani, "The Problems of Students' Narrative Text Writing Ability in SMAN 1 Ciamis," 2017.

[3] R. Kupiainen, "Classroom Strategies in Teaching the Media," Eesti Haridusteaduste Ajak., vol. 3, no. 3, pp. 104-129, 2015.

[4] K. Celuch, B. Bourdeau, and J. Smothers, "Thinking Innovatively about Teaching Innovation and Ideation: Getting Students to Think Differently," J. Res. Innov. Teach., vol. 7, no. 1, pp. 27-36, 2014.

[5] L. M. Byrne-davis, H. Dexter, J. Hart, and T. Cappelli, "Just-in-time research: A call to arms for research into mobile technologies in higher education," Res. Learn. Technol., vol. 23, no. 5, pp. 1-10, 2015, doi: 10.3402/rlt.v23.25653. 
[6] Virve Ruusunen, "Using Movies in EFL Teaching: The point of view of teachers," University of Jyväskylä, 2011.

[7] I. Hwang, M. Tam, S. L. Lam, and P. Lam, "Review of Use of Animation as a Supplementary Learning Material of Physiology Content in Four Academic Years Centre for Learning Enhancement and Research, The Chinese University of," Electron. J. e-Learning, vol. 10, no. 4, pp. 368-377, 2012.

[8] H. L. Sharma, "Enhancing students interest in English language via multimedia presentation," Int. J. Appl. Res., vol. 2, no. 1, pp. 275-281, 2016.

[9] M. Ismaili, "The Effectiveness of Using Movies in the EFL Classroom - A Study Conducted at South East European University," Acad. J. Interdiscip. Stud., vol. 2, no. 4, pp. 121-132, 2013, doi: 10.5901/ajis.2012.v2n4p121.

[10] H. Sabouri and M. Zohrabi, "The Impact of Watching English Subtitled Movies in Vocabulary Learning in Different Genders of Iranian EFL Learners," Int. J. Stud. English Lang. Lit., vol. 3, no. 2, pp. 110-125, 2015.

[11] L. Kabadayi, "The Role of Short Film in Education," Procedia-Soc. Behav. Sci., vol. 47, pp. 316-320, 2012, doi: 10.1016/j.sbspro.2012.06.657.

[12] D. Nunan, “Practical English.” Language Teaching, 1st ed. Yogyakarta: McGraw-Hill, 2005.

[13] B. F. Klimova, "The Importance of Writing," Paripex Indian J. Res., vol. 2, no. 1, pp. 9-11, Jan. 2012, doi: 10.15373/22501991/JAN2013/4.

[14] S. Peha, "The Writing Process Notebook," TTMS.org. TTMS.org, pp. 1-35, 2002.

[15] Abas, I. Hermilinda, and N. Aziz, "Model of the Writing Process and Strategies of EFL Proficient Student Writers: A Case Study of Indonesian Learners," Pertanika J. Soc. Sci. Humanit., vol. 26, no. 3, pp. 1-28, 2018.

[16] D. Bordwell and K. Thompson, Film Art: An Introduction, 8th ed. New York: McGraw-Hill Higher Education, 2012.

[17] A. Taşkın INAN, "Evaluation of contents of animated films by cartoon/animated film producers and teachers," IOSR J. Humanit. Soc. Sci. (IOSR-JHSS, vol. 21, no. 3, pp. 99-112, 2016, doi: 10.9790/0837-21030499112.

[18] F. C. Blumberg, K. P. Bierwirth, and A. J. Schwartz, "Does Cartoon Violence Beget Sggressive Behavior in Real Life? An opposing view," Early Child. Educ. J., vol. 36, no. 2, pp. 101-104, Oct. 2008, doi: 10.1007/s10643-008-0280-1.

[19] D. Özer and B. Avc, "Cartoons as Educational Tools and the Presentation of Cultural Differences via Cartoons," Procedia - Soc. Behav. Sci., vol. 191, no. 4419, pp. 418-423, 2015, doi: 10.1016/j.sbspro.2015.04.355.

[20] T. Sudarwati and E. Grace, Look Ahead 1. Erlangga, 2007.

[21] W. Kwon, Selecting Movies for English Language Learning \& Teaching: Criteria, Methodology, and a Movie Guide for ESL Learners \& Teachers (Introductions to M-ELT: Movie-assisted ESL Learning \& Teaching). Tomato's English, 2014.

[22] J. K, "Film in the Classroom," 1996.
[23] J. R. Fraenkel, N. E. Wallen, and Helen H. Hyun, How to design and evaluate research in education. New York: McGraw-Hill Humanities/Social Sciences/Languages., 2011.

[24] S. Singh, Advanced Sampling Theory with Applications, vol. 2. Springer Science \& Business Media., 2003.

[25] R. Burns, Introduction to Research Method. Australia: Longman, 2000.

[26] J. W. Creswell, Educational research: Planning, conducting, and evaluating quantitative and qualitative research, 3rd ed., vol. 4. Upper Saddle River, NJ: Prentice Hall, 2012.

[27] H. Haghverdy, "The Effect of Song and Movie on High School Students Language Achievement in Dehdasht," Procedia - Soc. Behav. Sci., vol. 192, pp. 313-320, 2015, doi: 10.1016/j.sbspro.2015.06.045.

[28] Z. Zainuddin, S. H. Halili, B. Aceh, and K. Lumpur, "Flipped Classroom Research and Trends from Different Fields of Study," Int. J. Instr., vol. 10, no. 1, pp. 133-150, 2017.

[29] Z. Zainuddin and M. Attaran, "Malaysian students' perceptions of flipped classroom: a case study Malaysian students' perceptions of flipped classroom: a case study," Innov. Educ. Teach. Int., vol. 53, no. 6, pp. 660-670, 2016, doi: 10.1080/14703297.2015.1102079.

[30] K. Merindriasari, I. Supardi, and Wardah, "The Use of Animated Short Film as Media for Teaching English Narrative Writing," J. Pendidik. dan Pembelajaran, vol. 4, no. 2, pp. 1-9, 2015.

[31] H. Khalidiyah, "The Use of Animated Video in Improving Students' Reading Skill (A Quasi-Experimental Study of Seventh Grade Student at A Junior High School in Jalancagak, Subang)," J. English Educ., vol. 3, no. 1, pp. 59-79, 2015.

[32] V. Ghaderi and J. Afshinfar, "A Comparative Study of the Effects of Animated versus Static Funny Pictures on Iranian Intermediate EFL Students' Intake and Retention of Idioms," Procedia - Soc. Behav. Sci., vol. 98, no. 2011, pp. 522-531, 2014, doi: 10.1016/j.sbspro.2014.03.448.

[33] T. Mosavi and F. Marvasti, "The Effects of Animation Usage on First Grade Reading," Br. J. Educ. Soc. Behav. Sci., vol. 10, no. 2, pp. 1-9, 2015, doi: 10.9734/BJESBS/2015/17784.

[34] H. Marashi and H. Adiban, "The Effect of Using Short Silent Animations on EFL Learners' Writing," J. English Educ., vol. 5, no. 2, pp. 207-216, 2017. 